\title{
Public Housing Construction and the Cities: 1937-1967
}

\author{
John F. McDonald \\ Heller College of Business, Roosevelt University, Chicago, IL 60605, USA \\ Correspondence should be addressed to John F. McDonald, mcdonald@uic.edu
}

Received 15 June 2011; Accepted 10 August 2011

Academic Editor: Andrejs Skaburskis

Copyright (C) 2011 John F. McDonald. This is an open access article distributed under the Creative Commons Attribution License, which permits unrestricted use, distribution, and reproduction in any medium, provided the original work is properly cited.

\begin{abstract}
Public housing advocates argue that the nation should expand the federal public housing program as part of an effort to increase the supply of affordable rental housing. This paper examines federal public housing construction in the largest US cities over the period 1937-1967, a period during which the public housing program was the primary program to provide low-income households with affordable rental housing. Public housing is found to depend upon the population level of the city, factors that characterize the housing stock as of 1950, the poverty level in the city, and the size of the nonwhite population in the city. The National Commission on Urban Problems (National commission on urban problems 1968, page 128) found that this supply response meant that "...the great need of the large central cities for housing for poor families was largely unmet." Changes in racial segregation from 1940 to 1960 are found to be unrelated to public housing construction. While the current situation is different in many respects from circumstances of these earlier decades, a renewed effort to supply public housing might produce similar outcomes.
\end{abstract}

\section{Introduction}

Passage of the Housing Act of 1937 was a political victory for the advocates of public housing in the US Numerous histories of public housing in the USA have been written; the recent book by Bradford Hunt [1] provides an informative, concise summary. Early urban reformers argued that slum housing contributed to numerous social problems, including poor sanitation, disease and poor public health, juvenile delinquency, crime, and social disorder. Local governments responded in the late 19th and early 20th centuries by passing building and housing codes, but these laws proved ineffective at substantially reducing the problems. One influential reformer/economist, Edith Elmer Wood, conducted research and wrote books to show that the private housing market was incapable of supplying decent housing at rents and prices that poor families could afford. In one book Wood [2] concluded that one-third of families could not be provided with acceptable housing (meeting a reasonable standard for size and quality) that was "affordable" (i.e., for rent of no more than $20 \%$ of income). As Hunt [1, page 19] suggests, this conclusion was the likely source of President Roosevelt's statement in his second inaugural address that one-third of the nation was ill-housed. Wood argued for direct government intervention for slum clearance and to supply housing for the poor. Wood did not consider demand-side subsidies_-housing vouchers.

Public housing advocates such as Bennett et al. [3] argue that it is time to consider an expansion of the current public housing program primarily to address the problem of the lack of affordable rental housing for households with low and moderate incomes. ${ }^{1}$ If it is worthwhile to consider expanding the public housing program, then it is also worthwhile to examine the history of the first public housing program. The purposes of this paper are to set out the basic rules of the public housing program as they existed from 1937 to 1968 , and to determine how local public housing officials (in conjunction with federal public housing officials) responded to the program. The focus of the paper is on the numbers of units constructed in the major cities, the numbers of equivalent demolitions of slum housing units in those cities, and the impact (if any) of the program on housing segregation. What lessons can be learned from this history?

Any conclusions that might be reached as to the relevance of this past history of public housing for current policy must be influenced by the fact that many factors are different from those that existed in the 1940s, 1950s, and 1960s. Current 
housing policy is a much more complex web of programs that includes federal demand-side housing vouchers, lowincome housing tax credits that enable the private sector to supply subsidized rental housing to households with modest incomes, and an ongoing program to replace the current public housing stock with mixed-income housing developments that include public housing. These programs are discussed briefly. Furthermore, it can be argued that the racial discrimination that was often prevalent in the earlier decades has declined, in part as a result of the civil rights laws that were passed beginning in the 1960s. Racial discrimination in the housing market is against the law. What is more, the national has undergone massive suburbanization, a sizable increase in the percentage of households that own rather than rent, significant demographic changes (with a large increase in the Hispanic population), but little progress has been made in reducing the rate of poverty since the early 1970s. Finally, the housing market has experienced great turbulence in recent years. Consider first the current problem of housing "affordability."

\section{The Problem of Rental Housing "Affordability"}

Today Americans at the lower end of the income distribution do not encounter housing problems as serious as those in the 1930s, but substantial problems remain. ${ }^{2}$ In spite of a variety of housing policies, households with modest incomes find that decent rental housing is "unaffordable" in many locations. Quigley and Raphael [4] provided an overview of the housing affordability problem up through 2000. Their study shows that:

(i) the poor rental household spent an average of $64 \%$ of income on housing in 2000, and $77 \%$ of the renter poor devoted more than $30 \%$ of their income to housing.

(ii) Renter households in the lowest $20 \%$ of the income distribution spent an increasing proportion of their incomes on housing - $47 \%$ in $1960,53 \%$ in 1980 , and $55 \%$ in 2000 . Households in this group that spent more than $30 \%$ of income on housing increased from $62 \%$ in 1960 to $69 \%$ in 1980 to $79 \%$ in 2000 .

Quigley and Raphael [4] reported that the primary cause of these increases in the 1980s and 1990s is an increase in rents rather than a decrease in the income of the lowincome population. Some of that increase in rents can be attributed to increases in quality (which partly stems from government restrictions through housing codes and building codes). However, it is also true that rents increased after adjusting for quality. Making rental housing more affordable depends upon increasing supply and increasing the effective income of low-income households.

It is worth noting that any definition of housing "affordability" as a percentage of income is arbitrary. The demand for housing is more properly considered to be a function of income averaged over a period of years, not just current income. For another thing, some households may simply
TABLE 1: Indicators of rental unit quality.

\begin{tabular}{lcc}
\hline & 1999 & 2009 \\
\hline Rental units (1000s) & 34,007 & 35,378 \\
Lacking full kitchen & $3.98 \%$ & $3.88 \%$ \\
Lacking full plumbing & $2.88 \%$ & $1.85 \%$ \\
(No exclusive use) & $1.62 \%$ & $1.58 \%$ \\
Year built (median) & 1966 & 1971 \\
Over 70 years old & $16.58 \%$ & $19.10 \%$ \\
Square feet in unit (median) & 1293 & 1300 \\
Square feet per person (median) & 523 & 520 \\
Persons per room & & \\
$\quad$ Up to 0.5 & $62.04 \%$ & $63.30 \%$ \\
0.51 to 1.00 & $33.06 \%$ & $32.46 \%$ \\
1.01 to 1.50 & $3.96 \%$ & $3.39 \%$ \\
$\quad 1.51$ and over & $0.94 \%$ & $0.79 \%$ \\
\hline
\end{tabular}

Source: American Housing Survey, 1999, 2009.

freely choose to spend a large percentage of income (in the longer run) on housing. So long as no laws are being broken and children are receiving adequate care, why should anyone else care? The real social problem arises if households with relatively low incomes must spend a large percentage of income just to obtain housing of some minimum standardand therefore are unable to afford other basic necessities. The size of the problem depends, of course, on the minimum standard for housing that society chooses to define. A referee reminds us that both the standard for minimum housing quality and the definition of "affordable" varies widely around the world.

The American Housing Survey provides an update on the status of rental housing in the USA Table 1 provides some summary measures of the quality of the rental housing stock in 1999 and 2009. These data suggest that the rental housing stock is of reasonably good quality. Very few units lack full kitchen or full plumbing facilities. Median unit size is 1300 square feet, and the crowding of units does not appear to be a serious problem. Only $4.2 \%$ of units had more than one person per room in 2009. However, Table 1 suggests that the quality of rental units had not increased very much from 1999 to 2009. The percentage of units that lacked complete plumbing facilities did decline from $2.9 \%$ to $1.9 \%$, and the percentage of units with more than one person per room dropped from $4.9 \%$ to $4.2 \%$, but the median age of units increased from 33 years to 38 years (and the percentage of units that were over 70 years old increased from $16.6 \%$ to $19.1 \%)$.

While the quality of rental units barely changed from 1999 to 2009 , rental housing costs as a percentage of household income increased sharply. Table 2 displays summary measures for 1999, 2007, and 2009. The year 2007 is included because 2009 was a recession year. Median monthly housing costs increased modestly from 1999 to 2007 (4.7\%) and 2009 $(6.6 \%)$, but the percentage of renter households that spent $30 \%$ or more of income on housing increased substantially. The percentage of renters that spent $30 \%$ or more increased 
TABLE 2: Monthly housing costs for rental households.

\begin{tabular}{|c|c|c|c|}
\hline & 1999 & 2007 & 2009 \\
\hline Monthly housing cost (median) & $\$ 580$ & $\$ 755$ & $\$ 808$ \\
\hline (corrected for inflation, \$1999) & $\$ 580$ & $\$ 607$ & $\$ 627$ \\
\hline Monthly housing cost as percent of household income (median) & $28 \%$ & $33 \%$ & $34 \%$ \\
\hline Monthly housing cost in excess of $30 \%$ of household income & $42 \%$ & $51 \%$ & $53 \%$ \\
\hline Monthly housing cost in excess of $40 \%$ of household income & $27 \%$ & $35 \%$ & $38 \%$ \\
\hline Monthly housing cost in excess of $50 \%$ of household income & $20 \%$ & $26 \%$ & $29 \%$ \\
\hline
\end{tabular}

Source: American Housing Survey, 1999, 2007, 2009.

TABLE 3: Units in government rent reduction programs (1000s).

\begin{tabular}{|c|c|c|c|}
\hline & 1999 & 2007 & 2009 \\
\hline Units under rent control & 884 & 560 & 529 \\
\hline Public housing units & 1,865 & 1,943 & 1,679 \\
\hline $\begin{array}{l}\text { Federal rent subsidy (HUD and } \\
\text { Department of Agriculture) }\end{array}$ & 2,062 & 3,196 & 3,185 \\
\hline $\begin{array}{l}\text { Other units with income } \\
\text { verification }\end{array}$ & 2,277 & 982 & 988 \\
\hline
\end{tabular}

Source: American Housing Survey, 1999, 2007, 2009.

from $42 \%$ in 1999 to $51 \%$ in 2007 to $53 \%$ in 2009 . The percentages of renters who spent more than $40 \%$ and $50 \%$ of incomes on housing increased by similar amounts. In 2009, $29 \%$ of renters spent at least $50 \%$ of their incomes on housing costs. The number of rental units with monthly housing costs of $\$ 349$ or less (in 1999 dollars) fell from 5,174,000 (15.2\% of rental units) in 1999 to $4,709,000$ (13.3\% of rental units) in 2009 (not shown in Table 2).

The American Housing Survey also reports the number of rental units that received some form of rent reduction. Table 3 shows the number of rental units that were included in the primary government programs. The total number of units covered by some form of public rent reduction program declined between 1999 and 2009. Units included in rent control programs fell by 355,000 units from 1999 to 2009. Public housing units increased by 78,000 from 1999 to 2007 , but declined by 264,000 units in the next two years as public housing authorities continued to demolish old, dysfunctional public housing units under the HOPE VI program. ${ }^{3}$ The federal rent subsidy programs operated primarily by HUD (with a smaller program administered by the department of agriculture) increased by $1,123,000$ units. ${ }^{4}$ These programs require that households pay $30 \%$ of their income in rent, with the remainder of fair market rent provided by the federal government. The number of units covered by a variety of programs that include some form of income verification (most of which involve a subsidy to the renter) declined sharply by $1,289,000$ units. ${ }^{5}$ The total number of units covered by all of the programs included in Table 3 declined from 7.088 million units to 6.381 million units from 1999 to 2009.

Is it time to consider expanding public rent reduction programs for households with modest incomes? As Quigley and Raphael [4] noted, making rental housing affordable involves both supply and demand elements. Government rent subsidies increase the effective purchasing power of the household, but do not directly bring about increases in supply. Perhaps it is time to consider an expansion of the public housing program. Public housing advocates argue that, once built, public housing units will serve for decadesprovided that they embody good design and are maintained and managed competently.

It is important that the argument for direct government intervention consists of three parts. First, a sizable fraction of the nation will continue to have low and moderate incomes. Second, the private market is unable to supply decent housing for the poor that is affordable. And third, the slum housing in which poor urban families live produces numerous negative externalities. The conclusion reached by Wood [2] was that government should respond in targeted fashion by supplying housing directly to poor families. The New Deal also included policies to attack the problem of poverty as well, of course, but private decisions cannot be relied upon to solve problems that involve significant negative externalities. Market failure means that the market fails to provide an efficient allocation of resources-in this case because the presence of negative externalities means that the decisions of private firms and households do not take social costs into account. The purpose of this paper is to determine the extent to which these basic economic factors - poverty and the poor quality of rental housing for the poor - can account for the amount of public housing that was constructed in the major cities of the USA during the first public housing program.

The paper examines the variation across major US cities in the number of public housing units that were constructed during the first 30 years of the program, 1937 to 1967 . The study ends with 1967 for two reasons. First, the rules of the program remained essentially intact during these years. The Housing Act of 1968 initiated a major change in urban housing policy. Second, 1967 marked the beginning of the peak of urban rioting and, as McDonald [5] suggests, the beginning of two decades of urban crisis in the US. A second purpose of the study is to examine whether the public housing program as implemented in the major cities had any impact on residential segregation. A well-known work of urban history by Hirsch [6] argues that public housing policy was an important element in the creation of what is called the "second ghetto." Hirsch suggests that the era of the creation of the "second ghetto" was 1937 to $1968 .{ }^{6}$ 


\section{The Federal Public Housing Program to 1967}

The federal public housing program in the USA began with the National Industrial Recovery Act in 1933. Senator Robert F. Wagner of New York inserted a clause that permitted the Federal Emergency Administration of Public Works (PWA) that was created by the Act to build low-cost housing and carry out slum clearance projects. The PWA Housing Division constructed some 22,000 units of publicly owned housing from 1933 to 1938 . This federal agency selected the sites, made the design choices, and managed the projects. Most of the units were built on vacant land because of a 1935 federal court ruling (in USA versus Certain Lands in the city of Louisville) that the federal government may not use eminent domain to acquire land for housing purposes. As Bradford Hunt [1, page 23] recounts, critics of the program argued that local control of public housing would respond better to local needs and that the high costs of the program led to rents that were too high for poor families. Furthermore, local control was needed because the federal court had ruled that only state and local governments may use the power of eminent domain for housing programs.

These considerations were built into the Wagner-Steagall Housing Act of 1937. The Act created the Local Housing Authority, an entity to be chartered by state statute, to select sites, make the design choices, manage the projects, and apply for the federal subsidies that were created. In most states the board of the Local Housing Authority is chosen by the mayor of the municipality. The federal subsidies were designed to keep rents low. A construction loan was provided that covered $90 \%$ of the total project costs (with $10 \%$ borrowed by the Local Housing Authority). In addition, the federal program provided annual cash payments equal to the total debt service for the project. In effect, the federal program paid for the entire capital cost of the project. The program also required that local governments contribute $20 \%$ of the annual subsidy for each project, but permitted exemption from local property taxes to count for that contribution. In effect public housing was exempt from local property taxes. All of this meant that rents for public housing needed only to cover management and maintenance costs. Rents could be set so that low-income households could afford public housing. The Act included the provision that rent shall be no more than $20 \%$ of annual family income (16.7\% for families of five or more). A final provision required "equivalent elimination," the clearance of one slum unit for each new unit, although a loophole permitted deferring equivalent elimination in the event of a local housing shortage. As Bradford Hunt [1, page 33] notes, these basic provisions remained in effect until adoption of the Housing Act of 1968. The public housing program began, and 160,000 units were constructed between 1939 and 1943, but only 10,000 additional permanent units were added from 1944 to 1948. Approximately 600,000 units of temporary housing were built during World War II (primarily in shipyard cities), and some of these units were in use until the 1950s.

The next landmark in the program is the Housing Act of 1949. This Act stated the goal to "... provide a decent,
Table 4: Municipalities with public housing: 1967.

\begin{tabular}{lcc}
\hline City size & Number of cities & Percent with public housing \\
\hline $10,000-25,000$ & 401 & 35 \\
$25,000-50,000$ & 198 & 46 \\
$50,000-100,000$ & 133 & 66 \\
$100,000-250,000$ & 74 & 90 \\
$250,000-500,000$ & 31 & 94 \\
Over 500,000 & 20 & 95 \\
\hline
\end{tabular}

safe, and sanitary living environment ... for every American." The Act authorized construction of 135,000 units of public housing per year for 6 years $(810,000$ units), so it was envisioned that almost 1 million units of public housing would exist by 1955 . According to the National Commission on Urban Problems [7, page 110], it was thought that approximately 4 million people could be living in public housing by 1955-enough for a very significant reduction in the shortage of housing for the poor. The Act changed the $20 \%$ contribution by local government to a cash payment of $10 \%$ of comparable shelter rents (with property tax exemption). Rents in public housing were required to be at least $20 \%$ below the lowest rents at which decent private apartments were supplied. And preference was to be given to those displaced by public slum clearance or redevelopment projects. The National Commission on Urban Problems [7, page 111] argued that this last provision was unfortunate in that it was "problem" households that were unable to cope with displacement on their own. Actual construction was 463,000 units from 1949 to 1967 (with another 41,000 in process), so that 633,000 units of public housing were in operation in 1967.

The National Commission on Urban Problems [7, page 112] reported that nearly all of the large cities in the nation participated in the public housing program. Table 4 shows the percentage of cities in each size class that participated in the public housing program as of 1967. Table 4 shows that the percentage of cities that participated increased sharply with city size. Forty-eight of the 51 cities with population in excess of 250,000 had federal public housing.

\section{Public Housing in the Major Cities}

The purpose of this section is to estimate a model of the determinants of the size of the public housing stock in a city as of 1967. The study includes the top 50 cities in the USA as determined by the 1960 census, excluding the three that did not participate in the public housing program (Long Beach, San Diego, and Tulsa) and Honolulu, Hawaii (which was not a state until 1959). The empirical results below suggest why Long Beach, San Diego, and Tulsa were not participants in the program in 1967 . These were relatively small cities in 1950 (populations of $251,000,334,000$, and 182,000, resp.) with high rates of home ownership and small minority populations. The 46 cities that participated in the program had 113,603 units of public housing in service in 1949 (66.8\% of the national total) and added 205,051 units between 1949 
and 1967 (44.3\% of the total units added in the nation during these years). As of 1967 these top 46 cities contained 50.3\% of the public housing built under the federal public housing program.

The decision to request funds to construct public housing rested with the Local Housing Authority (and required approval by municipal officials in most cases), so what determined the magnitude of those requests? Approval of the proposals by the US Housing Authority was required, of course, but the initiative was with the local officials. As the National Commission on Urban Problems described, federal funding for the program varied from year to year and administration to administration, so this study examines the long run outcome- the total stock of public housing in service in 1967. The year 1967 is chosen because the Housing Act of 1968 marked a major change in federal housing policy. The focus is the result of the original public housing program as initiated in 1937 and extended in 1949.

What basic economic factors are likely to determine the size of the request made by the Local Housing Authority and the approval by the US Housing Authority? The most obvious variable is the population of the city. Holding other factors constant, a larger city has a greater need for public housing. Indeed, the simple correlation between the size of the public housing stock in 1967 and the population of the city in 1960 is 0.95 . However, it is clear that there is much more to the story. Consider the five largest cities in 1960. New York City (with population 7.78 million) had 64,633 units of federally funded public housing (plus units funded by state and local funds), Chicago (population 3.55 million) had 32,960 federally funded units, and Philadelphia (population 2.00 million) had 15,719 units. But Los Angeles (population 2.48 million) had only 9,287 units and Detroit (population 1.67 million) had 8,180 units.

As noted above, the basic hypothesis in this study is that the demand for public housing in a city depends upon the characteristics of the private housing stock and the local population. Characteristics of the private housing stock that may be important include the following.

(i) The age of the housing stock, measured as the percentage of the housing stock in 1950 that was constructed after 1940. Very little construction took place in the 1930s, so this variable in effect measures the percentage of housing that was built before 1930 .

(ii) The percentage of the occupied housing stock that is owner occupied. Since public housing is rental housing, a larger rate of ownership means a smaller demand for rental housing.

(iii) The percentage of units with hot running water, private toilet and bath, and not dilapidated. This is the basic measure of "standard" quality used by the census.

(iv) The vacancy rate. This is an ambiguous indicator in that a high vacancy rate can mean an ample supply of rental housing, or it can mean that the supply is of low quality. (v) Population density in the city, to measure the extent to which the city is crowded-possibly with unhealthy tenement structures.

These variables are taken from the 1950 Census of Population and Housing on the grounds that this census reflected the situation after the first wave of public housing construction from 1937 to 1949 and the state of the housing stock to which local officials responded in formulating their requests for additional public housing in the 1950s.

The intent of the public housing program was to provide decent housing for poor families, so the percentage of lowincome families should be relevant. The official federal poverty definition did not exist in 1950, but the 1950 Census of Population and Housing provides data on the percentage of families with incomes below $\$ 2,000$ per year in 1949. A second population characteristic is also tested-the percentage of the population that was nonwhite. This is the measure of the minority population that was provided by the censuses of 1950 and 1960. The motivation for testing this variable has two parts. First, it may be that, among families with incomes below $\$ 2,000$, the incomes of nonwhites were less than the incomes of whites. If the public housing program is responding to the number of families in extreme poverty, then inclusion of the nonwhite percentage may add to the explanatory power of the model. However, it has been alleged (and in the case of Chicago, demonstrated in federal court) that site selections for public housing sometimes were used to maintain racial segregation. If local jurisdictions were motivated to confine the nonwhite population to certain areas within the city, then the Local Housing Authority might apply for more public housing-especially the high-density variety that was constructed in the 1950s and early 1960s. Hirsch [6] provided a detailed examination of this hypothesis in the case of Chicago in his well-known book Making the Second Ghetto: Race and Housing in Chicago, 1940-1960. This hypothesis is now known as the "second ghetto" school and is the subject of a voluminous literature, including a special issue of the Journal of Urban History in 2003. The percentages of nonwhite population for both 1950 and 1960 are used in this study to test whether the situation as of 1950 or the trend as reflected in the figure for 1960 is more relevant. A second approach to testing for the effects of race is to include an index of segregation as provided by $\mathrm{K}$. Taeuber and A. Taeuber $[8] .^{7}$

The variable definitions, means and standard deviations, and data sources for the 46 major cities, are shown in Table 5. Public housing units per 1,000 population, as provided by the National Commission on Urban Problems [7, page 85] has a mean of 8.96, with a minimum of 0.80 (Rochester, NY) and a maximum of 26.89 (Newark). While New York City had 64,633 units, its units per 1,000 population was only average at 8.30 . Note in 1950 the low mean of $76.7 \%$ for the percentage of housing with hot running water, complete bathroom facilities and not dilapidated, and the very low mean vacancy rate of $1.64 \%$. The mean in 1950 for families with incomes below $\$ 2,000$ was $21.6 \%$, and the mean for nonwhite population was $14.1 \%$ in 1950 (19.6\% in 1960). 
TABLE 5: Variable definitions and descriptive statistics: 46 major US cities.

\begin{tabular}{lccccc}
\hline Variable & Mean & Std. Dev. & Minimum & Maximum & Data source \\
\hline Public housing units per 1000 population & 8.96 & 4.35 & 0.80 & 26.89 & National Commission on Urban Problems \\
Percentage of housing stock built after 1940 & 15.85 & 9.80 & 3.1 & 36.3 & 1950 Census \\
Percentage housing owner occupied & 45.92 & 10.60 & 19.1 & 64.0 & 1950 Census \\
Percentage housing standard quality* & 76.76 & 10.26 & 56.0 & 91.0 & 6.70 \\
Vacancy rate (\%) & 1.64 & 1.23 & 0.50 & 39.4 & 1950 Census \\
Percentage families, income $<\$ 2,000$ & 21.57 & 6.43 & 13.1 & 39.9 & 1950 Census \\
Percentage Nonwhite population, 1950 & 14.11 & 9.92 & 1.6 & 54.8 & 1950 Census \\
Percentage Nonwhite population, 1960 & 19.59 & 11.87 & 2.7 & 97.8 & K. Taeuber and A. Taeuber [8] \\
Segregation index, 1950 & 88.29 & 4.35 & 76.9 & 25,046 & 1950 Census \\
Population density per square mile & 9,496 & 5,294 & 2,861 & &
\end{tabular}

${ }^{*}$ Units with hot running water, private toilet and bath, and not dilapidated.

Table 6: Regression analysis of public housing units per 1,000 population* $(n=46)$.

\begin{tabular}{lcccc}
\hline Independent variable & $(1)$ & $(2)$ & $(3)$ & $(4)$ \\
\hline Constant & 14.496 & 12.922 & 9.515 & 25.875 \\
& $(4.59)$ & $(3.93)$ & $(2.87)$ & $(2.41)$ \\
Percentage housing & -0.287 & -0.261 & -0.195 & -0.167 \\
Owner occupied & $(5.43)$ & $(4.75)$ & $(3.38)$ & $(2.84)$ \\
Percentage families & 0.355 & 0.435 & 0.378 & 0.418 \\
Income < 2 2,000 & $(4.07)$ & $(4.30)$ & $(3.97)$ & $(4.32)$ \\
Percentage of housing & - & -0.126 & -0.134 & -0.143 \\
Stock built after 1940 & & $(1.83)$ & $(2.04)$ & $(2.22)$ \\
Percentage Nonwhite & - & - & 0.119 & 0.116 \\
Population, 1960 & & & $(2.44)$ & $(2.42)$ \\
Segregation index, & - & - & - & -0.207 \\
1950 & & & & $(1.60)$ \\
$R$-squared & 0.522 & 0.558 & 0.614 & 0.637 \\
Adjusted $R$ sq. & 0.500 & 0.526 & 0.576 & 0.592 \\
\hline
\end{tabular}

* Unsigned $T$ values in parentheses.

Multiple regression models were estimated, and the results of four of the models are shown in Table 6. The dependent variable is public housing units per 1,000 population. Preliminary tests revealed that the percentage of housing that was owner occupied, and the percentage of families with income less than $\$ 2,000$ are the variables that have the highest correlation with the dependent variable. The results for the estimated equation that includes these two variables are shown in column (1) of Table 6. As expected, the percentage of housing that was owner occupied is estimated to have had a negative association with public housing units, and the measure of poverty has a positive association with public housing units. Both of these variables attain a high level of statistical significance ( $t$ statistic well in excess of 2.0, the conventional standard for $95 \%$ level of confidence that the estimated coefficient is not zero), and the $R$-squared for the estimated equation is 0.52 . Other variables that measure the nature of the housing stock were tested by adding each variable individually to the specification in column (1).
These include the vacancy rate, population density, the percentage of units of standard quality (hot water, full bathroom, and not dilapidated), but the only variable that adds explanatory power is the percentage of units that were built after 1940. Column (2) of Table 6 contains the results for the estimated equation that includes this last variable, which attains marginal statistical significance $(t=1.83)$ with the anticipated negative sign. The variable percentage of units of standard quality is highly negatively correlated with percentage of families with income below \$2,000 (simple correlation of -0.75 ), so it is no surprise that it adds little to the explanatory power of the model.

The estimated equation in column (2) of Table 6 is a reasonably simple model of the public housing units per 1,000 population in the major cities as of 1967 , but it is important to test for any impact of race on the program. The percentage of nonwhite population in the city is added to the estimated equation in column (3) of Table 6. This estimated coefficient of this variable is positive and statistically significant, indicating that cities with larger percentages of nonwhite population built more public housing per 1,000 population, holding constant the effects of owner-occupancy, poverty (as measured), and newer housing stock. The coefficient of 0.119 means that an increase in the nonwhite population of $10 \%$ was associated with an increase in public housing per 1,000 population of 1.19 units. Recall that the mean value for the dependent variable is 8.96 , so this estimated coefficient has social and economic significance as well as statistical significance. The percentage of nonwhite population has a range of $2.7 \%$ to $54.8 \%$ in the 46 cities in the study. In addition, the estimated coefficient of the percentage of housing stock built after 1940 is now statistically significant at conventional levels $(t=$ 2.04).

A final test, shown in column (4) of Table 6, is to include the K. Taeuber and A. Taeuber [8] index of segregation for 1950. The estimated coefficient of this variable is negative, and attains marginal statistical significance $(t=1.60)$. It may have been that cities with lower levels of segregation were more accepting of public housing. ${ }^{8}$

The model was estimated using the actual number of public housing units (PHU) as the dependent variable and 
population of the city in 1960 as an additional independent variable. The estimated equation is

$$
\begin{aligned}
\text { PHU }= & \underset{(1.34)}{3508.99}+\underset{(23.19)}{7.54} \text { POP60 } \\
& -\underset{(3.03)}{131.29} \text { OWNOCC }+\underset{(2.76)}{182.80} \text { POVERTY } \\
& -\underset{(2.27)}{102.90} \text { BLTAFT40 }+\underset{(1.46)}{48.75} \text { NONWHITE60. }
\end{aligned}
$$

Unsigned $T$ values are in parentheses, and the $R$-squared for the estimated equation is 0.953 . The variables are defined as follows:

POP60 = population of the city in 1960 in 1000s,

OWNOCC $=$ percentage of occupied units owner occupied in 1950,

POVERTY $=$ percentage of families with income below $\$ 2,000$ in 1949 ,

BLTAFT40 = percentage of housing units in 1950 built after 1940,

NONWHITE60 $=$ percentage of population nonwhite in 1960.

Note that, except for percentage of nonwhite population, the coefficients of all of the variables attain high levels of statistical significance. The coefficient of the percentage of nonwhite population is positive as expected with statistical significance at the $93 \%$ level for a one-tail test ( $86 \%$ level for a two-tail test). In this case, the addition of the segregation index for 1950 (not shown) did not add to the explanatory power of the model.

In summary, the empirical results in Table 6 demonstrate that a simple empirical model can "explain" the choices that were made regarding the construction of public housing in the major cities in the USA under the program as it existed from 1937 to 1967. Cities with more owner occupied housing built fewer public housing units, and cities with greater rates of poverty built more units. Cities that had more new housing built fewer units. These results are as one would have expected given that the public housing program was intended to provide decent housing for the poor. And, holding these factors constant, cities with greater numbers of nonwhite population received more public housing units. This finding suggests, but does not prove, that the public housing program was being used by local authorities to promote racial segregation. More evidence on this question is provided in the next section.

The estimated models can be used to compute expected values of public housing units, which can be compared to actual values. The above model for the actual number of public housing units is employed, and the results of the computations for the top 20 cities are shown in
Table 7. Note that expected and actual units for New York City, Chicago, and Philadelphia are different by only small amounts (2.4\% for New York, $10.2 \%$ for Chicago, and $0.8 \%$ for Philadelphia). On the other hand, the model produces expected units for Los Angeles that are almost twice as large as the actual number of units. A similar result is obtained for Houston. Actual construction in Detroit was 26\% below the number predicted by the model. Other cities, such as Baltimore, Washington, DC, Dallas, and New Orleans built more public housing units than expected according to the model. Aiken and Alford [9] provided evidence that public housing construction was influenced by political as well as economic factors.

Those political factors are the subject of detailed studies of Los Angeles by Don Parson [10] and of Detroit by Sugrue [11]. Don Parson [10] argues that the public housing program in Los Angeles was derailed by accusations in the early 1950s that the local housing authority was infiltrated by communists. In any case, construction of public housing in Los Angeles ended in 1955, and the city shifted to other efforts at urban renewal that had the support of the local business community. Sugrue [11] suggests that public housing in Detroit lost support because of the fear by mainly white home owners that public housing meant invasion of their neighborhoods by poor African Americans. Detroit is a city dominated by the Democratic party, but Republican Albert Cobo was elected mayor of Detroit in 1949 on a platform that included ending the construction of public housing. However, Table 7 shows that public housing construction in Detroit fell short of the expected amount by $26 \%$ (2904 units). The model generates a relatively small number of public housing units for Detroit because of the high rate of home ownership in the city of $53.9 \%$, the relatively low poverty rate, and the relatively large volume of housing construction after 1940.

The influences of the variables included in the model can be seen in Table 7. For example, Baltimore and Houston had virtually identical population levels, poverty rates, and percentages of owner occupancy. However, Baltimore had large nonwhite population and fewer housing units built after 1940 — and therefore a larger expected number of public housing units by $44 \%$. While St. Louis and Milwaukee had roughly equal population levels, St. Louis had greater nonwhite population and poverty rate and smaller rate of owner occupancy and fewer newer housing units-with the result that expected public housing units are larger by $85 \%$ (and more actual units by $136 \%$ ). Milwaukee and San Francisco provide another example of two cities with identical population levels. San Francisco had greater percentage of newer housing units, but this factor was more than offset by a larger nonwhite population, a greater poverty rate, and a lower rate of owner occupancy.

A second feature of the public housing program was equivalent elimination - the requirement for the elimination of unsafe and unsanitary dwellings in the same numbers as the newly built public housing units. However, there was a major loophole in the law. Equivalent elimination could be deferred if there was a shortage of decent units that was so severe that elimination of units would cause dangerous 
TABLe 7: Expected and actual public housing units.

\begin{tabular}{|c|c|c|c|c|c|c|c|}
\hline City & Expected units & Actual units & $\begin{array}{c}\text { Population } 1960 \\
(1000 \mathrm{~s})\end{array}$ & $\begin{array}{c}\text { Percent } \\
\text { Nonwhite }\end{array}$ & $\begin{array}{c}\text { Poverty } \\
(\text { Inc }<\$ 2,000)\end{array}$ & $\begin{array}{c}\text { Percent } \\
\text { Owner-Occ. }\end{array}$ & Built after 1940 \\
\hline New York & 63,083 & 64,633 & 7,782 & 14.7 & 19.4 & 19.1 & 8.4 \\
\hline Chicago & 29,596 & 32,960 & 3,550 & 23.6 & 14.5 & 30.4 & 4.8 \\
\hline Los Ang. & 18,330 & 9,287 & 2,479 & 16.8 & 21.2 & 45.8 & 25.0 \\
\hline Phil. & 15,590 & 15,719 & 2,003 & 26.7 & 21.6 & 56.1 & 7.9 \\
\hline Detroit & 11,084 & 8,180 & 1,670 & 29.2 & 13.2 & 53.9 & 17.4 \\
\hline Balt. & 8,095 & 10,335 & 939 & 35.0 & 22.7 & 51.7 & 15.3 \\
\hline Houston & 5,615 & 2,599 & 938 & 23.2 & 22.9 & 50.1 & 36.3 \\
\hline Cleveland & 8,444 & 7,458 & 876 & 28.9 & 17.4 & 42.7 & 6.4 \\
\hline Wash DC & 8,641 & 10,056 & 764 & 54.8 & 17.6 & 32.3 & 22.3 \\
\hline St. Louis & 9,907 & 7,245 & 750 & 28.8 & 23.5 & 34.8 & 3.8 \\
\hline Milw’kee & 5,350 & 3,066 & 741 & 8.9 & 13.1 & 43.0 & 9.1 \\
\hline San Fran. & 6,689 & 5,883 & 740 & 18.4 & 16.2 & 36.7 & 14.1 \\
\hline Boston & 9,291 & 10,973 & 697 & 9.8 & 21.0 & 24.9 & 5.1 \\
\hline Dallas & 2,752 & 6,372 & 680 & 19.3 & 20.5 & 53.0 & 35.4 \\
\hline New Orl. & 9,902 & 12,270 & 628 & 37.4 & 33.2 & 33.8 & 17.6 \\
\hline Pittsb. & 6,537 & 9,234 & 604 & 16.8 & 21.2 & 42.4 & 6.4 \\
\hline San Ant. & 3,903 & 5,563 & 588 & 7.4 & 33.3 & 56.4 & 30.2 \\
\hline Seattle & 1,638 & 3,520 & 557 & 8.4 & 16.3 & 56.5 & 20.0 \\
\hline Buffalo & 5,381 & 4,370 & 533 & 13.8 & 17.9 & 43.6 & 3.6 \\
\hline Cincy & 7,091 & 6,222 & 503 & 21.8 & 25.0 & 37.9 & 8.5 \\
\hline
\end{tabular}

overcrowding. Furthermore, elimination of any units by a public body in the jurisdiction counted towards the equivalent elimination requirement. The National Commission on Urban Problems [7, page 85] reported that the total number of equivalent eliminations for the 46 cities in this study was 126,408 as of December 1963, compared to 318,654 units of public housing in service in 1967. Eliminations through 1949 were 72,316 units compared to 114,535 units constructed (a ratio of 0.631 ), but through the end of 1963 only 54,136 additional units had been eliminated compared to 204,119 additional public housing units constructed (a ratio of 0.265 ). Nevertheless, it is clear that the number of equivalent eliminations was driven by construction of public housing units. A simple linear equation for the 46 cities in the study is estimated as follows:

$$
\begin{aligned}
& \text { equivalent eliminations } \\
& \qquad=\underset{(1.88)}{562.03}+\underset{(13.00)}{0.316} \text { public housing units. }
\end{aligned}
$$

Equivalent eliminations are the total through the end of 1963, and public housing units are the units in service in 1967. The $R$-squared for the estimated equation is 0.793 , and $T$ values are in parentheses. The equation says that an additional 100 units of public housing were associated with 32 units eliminated, and this estimated coefficient is statistically significantly less than 1.0 (but recall that the measure of units eliminated lags behind the measure of units constructed by four years).
An alternative specification relates equivalent eliminations per 1,000 population $(\mathrm{EE} / 1,000)$ to public housing units per 1,000 population (PHU/1,000). The estimated equation is

$$
\mathrm{EE} / 1,000=\underset{(0.09)}{0.60}+\underset{(6.94)}{0.46 \mathrm{PHU} / 1,000 .}
$$

$T$ values are in parentheses, and the $R$-squared for this estimated equation is 0.523 . This equation says that an increase in public housing units per 1,000 of 1.0 was associated with an increase in equivalent eliminations per 1,000 population of 0.46 (an estimated coefficient that is statistically significantly less than 1.0). Several additional variables were tested, including percentage of housing owner occupied, percentage of families with income below $\$ 2,000$, percentage of housing units built after 1940, and percentage of nonwhite population in 1960. None of these variables has an estimated regression coefficient that attains statistical significance. The conclusion from these tests is that equivalent eliminations were closely related to public housing units constructed, but that units eliminated systematically fell short of units constructed.

\section{Segregation and Public Housing}

Racial segregation of the African-American population was and is a prominent feature of all major cities in the USA The landmark study of racial segregation by K. Taeuber and 
TABLe 8

\begin{tabular}{lcc}
\hline Year & Mean of segregation indices & Range \\
\hline 1940 & 86.45 & 77.0 to 98.0 \\
1950 & 88.29 & 76.9 to 97.9 \\
1960 & 86.79 & 69.3 to 97.9 \\
\hline
\end{tabular}

TABLE 9

\begin{tabular}{lcc}
\hline Years & Mean of change in index & Range of change \\
\hline $1940-60$ & 0.35 & -13.6 to 14.4 \\
$1950-60$ & -1.49 & -10.5 to 6.2 \\
\hline
\end{tabular}

TABLE 10: Regression analysis of change in segregation index* (44 cities).

\begin{tabular}{lcc}
\hline Independent variable & $\begin{array}{c}\text { Change in segregation } \\
\text { index: 1940 to 1960 }\end{array}$ & $\begin{array}{c}\text { Change in } \\
\text { segregation index: } \\
1950 \text { to 1960 }\end{array}$ \\
\hline Constant & -2.277 & -3.625 \\
Public housing & $(1.16)$ & $(3.26)$ \\
Units per 1,000 & -0.048 & -0.013 \\
Percentage change in & $(0.31)$ & $(0.02)$ \\
population of city & 0.050 & 0.041 \\
Change in percentage & $(2.32)$ & $(1.77)$ \\
Nonwhite population & -0.203 & -0.132 \\
Percentage Nonwhite & $(1.66)$ & $(1.17)$ \\
Population in 1950 & 0.197 & 0.172 \\
$R$-squared & $(2.21)$ & $(3.02)$ \\
Adjusted $R$-sq. & 0.460 & 0.409 \\
\hline
\end{tabular}

${ }^{*}$ Unsigned $T$ values are in parentheses.

A. Taeuber [8] provided data on an index of segregation for 44 of the 46 cities included in this study. The index indicates the percentage of nonwhite population in the city that would have had to change residential location to produce an equal percentage of African-Americans in each census block in the city. The means and ranges for the segregation indices for the 44 cities for 1940, 1950, and 1960 are as in Table 8.

Some indices of segregation changed from decade to decade. The means and ranges for the changes in the indices for the 44 cities are as in Table 9.

The change in a segregation index is a complex result of several factors. Cities change. Some cities expanded their boundaries and others did not. Some cities experienced population growth, while others experienced population decline. Some cities were major destinations for the "great migration" of African Americans from the South during these decades, but others were not. The percentage of African-American population was high in some cities and low in others. And some cities built more public housing than did others.

The purpose of this section is to estimate a model of the change in the index of segregation that includes the number of public housing units per 1,000 population. Is public housing associated with an increase or a decrease in segregation? Or does the evidence indicate that changes in segregation were unrelated to public housing? The "second ghetto" hypothesis is not clear as to whether public housing increased segregation or tended to maintain a given level of segregation. Hirsch [6], the originator of the "second ghetto" hypothesis, argues that the "first ghetto" emerged from 1880 to 1933 and was based almost entirely on private decisions. The period of the hypothesized "second ghetto" is 1933 to 1968 , a time in which the actions of the public sector are deeply implicated in the creation of a second ghetto in place of the first ghetto. His detailed examination of Chicago places public housing at the center of the creation of the second ghetto. In contrast, Seligman [12] points out that public housing never contained more than $10 \%$ of the African-American population in Chicago, and that this population grew substantially over these years while the pattern of racial segregation was maintained. Seligman [13] followed up these comments with a detailed study of racial transition in neighborhoods in Chicago that contained no public housing.

What factors are associated with changes in segregation during the 1940s and 1950s? K. Taeuber and A. Taeuber [8, page 75] showed that one important factor is an increase in the nonwhite population, which they found to be related to reductions in segregation. The change in the percentage of the population of the city that was nonwhite is included in the model on the grounds that an increase in this percentage is likely to cause some neighborhood racial boundaries to break down as the housing market adjusts. Another control variable is the change in the population of the city. This variable controls for changes in the boundaries of the city. For example, suppose that a city annexed some suburban area that contained only white population. This action means that a larger fraction of the minority population would have to change residential location in order to create "perfect" integration at the census tract level, and hence the segregation index is greater. ${ }^{9}$ A third control variable is the percentage of the population of the city that was nonwhite in 1950. This variable controls for the possibility that white resistance to integration may have been greater the larger was the nonwhite population relative to the white population. White and nonwhite are the designations used by the US Bureau of the Census in 1950 and 1960.

Estimates of multiple regression models of the change in the segregation index are shown in Table 10. Changes in the indices are examined for 1940 to 1960 and 1950 to 1960 . The results in Table 10 show that, as expected, with one exception, the three control variables have estimated coefficients that attain (or nearly attain) conventional levels of statistical significance. The signs of the estimated coefficients are as expected. A greater percentage increase in the population of the city is associated with a larger increase in the segregation index as expected. A larger increase in the percentage of the population of the city that was nonwhite is related to a larger decline in the segregation index (although the coefficient does not attain statistical significance for the change in the segregation index from 1950 to 1960). And a larger 
percentage nonwhite population in 1950 is related to a larger increase in the segregation index.

The estimated coefficient of the public housing variable is not statistically significantly different from zero for either time period. This evidence suggests that the change in the segregation index was not related to the units of public housing per 1,000 population. According to one version of the "second ghetto" hypothesis, the public housing program was operated to maintain an existing level of segregation. The evidence in Table 10 suggests that the public housing program did not reduce segregation, and that it did not tend to increase segregation. Rather, the results in Table 10 suggest that the public housing program was essentially not an important determinant of the changes in the overall level of segregation. This finding is consistent with two hypotheses; the public housing program was too small to have much impact on changes in segregation, or the program was operated so as not to alter the level of segregation. Indeed, perhaps both hypotheses are correct. However, research by Carter et al. [14] found that the presence of public housing was associated with an increase in the poverty rate in nearby census tracts in four major central cities in the USA from 1950 to 1990 . The idea that a greater concentration of poverty within a central city may lead to a greater demand for more public housing has not been tested. Nevertheless, this study has shown that a greater poverty rate in the city overall was associated with the construction of more public housing.

\section{Conclusion}

This study shows that the quantity of public housing that was constructed in 46 major cities in the first 30 years of the program largely can be explained by a small number of variables: the population of the city, the nature of the housing stock, the incidence of poverty, and the percentage of nonwhite population. Equivalent eliminations of slum housing units (a requirement in the law) were driven by the construction of public housing units, but equivalent elimination systematically fell far short of public housing construction. An examination of the possible effect of public housing on racial segregation finds that changes in racial segregation in the major cities were not related to the volume of public housing constructed. The first public housing program, for good reasons, relied on local officials to initiate proposals for public housing construction. It is reasonable to presume that any new public housing initiative similarly would rely on local officials, and that their responses might be similar to those of their earlier counterparts. Larger cities and cities with lower rates of home ownership, an older rental housing stock, and more poor people will request more public housing construction. Cities with a greater proportion of minority population will request more public housing, but the program will have no impact on the level of racial segregation. Other local and policy factors will influence requests as well. For example, the demand for public housing may be influenced by the number of Housing Choice Vouchers supplied by the federal government and by the amount of low-income housing tax credits allocated to the state (and allocated to the city by the state). The massive suburbanization of the population has left minority populations with greater political influence in many of the major central cities. This factor may result in greater demands for public housing, other factors equal, than was revealed in the first three decades of the federal program. And the massive wave of mortgage defaults that has taken place since starting in 2007 has turned large numbers of households from home owners to renters. The rate of home ownership has declined from a high of $69 \%$ to $65 \%$ and shows signs of further declines. As the estimated models suggest, a reduction in the rate of home ownership increases the demand for public housing.

The National Commission on Urban Problems [7] provided an assessment of the public housing program at that time. That assessment was generally positive, but included recommendations for significant changes in the program. The Commission [7, pages 118-119] found that vacancy rates in public housing were very low in most of the major cities- $0.2 \%$ in New York, $0.5 \%$ in Chicago, 3.6\% in Los Angeles, and $1.4 \%$ in Philadelphia, for example. Waiting lists were very large relative to the number of vacant units, and turnover rates were lower than in the private rental housing market. The Commission favored an expansion of the public housing program provided that defects in the program were addressed. The problems with the program identified include the following:

(i) delays in planning, approval, and construction of projects,

(ii) failure to take advantage of construction cost reductions,

(iii) construction of too many high-rise projects [7, page 119] “... which make a better communal life very difficult and identify the occupants as dwellers of "poor towns."”

(iv) disregard of the needs of large families by building apartments with two bedrooms or fewer,

(v) rents required to pay expenses meant that units tended to be occupied by families with incomes at or just below the income limits so the very poorest families were not being served,

(vi) neglect of services for tenants, attractive design for the projects, and training for public housing personnel.

The Commission [7, page 128] criticized “... the sorry showing in the volume of public housing built over the past 30 years." The Commission reached the conclusion [7, page 128] that "... the great need of the large central cities for housing for poor families was largely unmet." The conclusions of the Commission surely influenced subsequent policy decisions, including the creation of the Housing Choice Voucher (Section 8) program. If the record of a new public housing program turns out to be comparable to the results of the first public housing program, the combination of local requests and federal funding will produce results that will fall far short of the need. 
The Commission did not foresee, and perhaps could not have foreseen, the disaster that public housing became in the coming decades in several large cities (with New York City as a major exception). At least two of the criticisms of the program listed above proved to be prescient. Many of the high-rise projects became centers of poverty, crime, and social disorder. And the neglect of services for tenants, of attractive design, and of good management practices contributed to the coming disasters. See Bradford Hunt [1] for a detailed history of the Chicago program. Any new public housing program must heed these lessons as well. ${ }^{10}$

\section{Endnotes}

1. Bennett et al. [3, page 11] state that given the foregoing reality, the scaling down of the public housing program as a component of America's social safety net represents a cruel and destructive strategy. The editors and contributors to this volume are in agreement that a new era of affordable housing development and maintenance is long overdue. Nevertheless, in order to ensure that there will be an adequate supply of affordable housing widely available across urban America, the public sector must play a strong role either as the direct producer of affordable housing or as fiscal enabler and regulator of the affordable housing initiatives implemented by nonprofit and for-profit organizations.

2. Another book by Wood [15, page 35] documents housing conditions in 1934. Of 1.815 million occupied housing units in the city of New York, $21.3 \%$ had no central heat, $13.5 \%$ had no hot water, $13.0 \%$ had no bath tub or shower, and $10.4 \%$ had no "private indoor water closet." A survey of 64 cities [15, page 82] found that $5.0 \%$ of occupied units had no running water, $13.5 \%$ had no "private indoor water closet," and $20.2 \%$ had no bath tub or shower.

3. The Housing Opportunities for People Everywhere (HOPE VI) program began in 1993 as an effort to enable local public housing agencies raze or rehabilitate deteriorated public housing units and to transform the "projects" into low-density public housing communities. The largest HOPE VI effort has been active in Chicago since 1999. See Bennett et al. [3] for details and extensive critique.

4. Most of the units are part of the Section 8 program (since renamed Housing Choice vouchers) created by the 1974 Housing and Community Development Act.

5. These programs include FHA low-interest loans and mortgage insurance for the construction of rental housing for households with low and moderate incomes. This program began as Section 221(d)(3) and related sections of the National Housing Act of 1954. The rental housing developments can participate in the program for a maximum of 40 years. Other units were constructed under Section 236 of the Housing and Urban Development Act of 1968, and the program continued until 1983 under the 1974 Housing and Community
Development Act. Included in this category as well are rental units built using federal Low Income Housing Tax Credits, a program that began in 1986. Units remain affordable at least for the life of the tax credit, which is 15 years. Also included are units constructed under the HOME program (begun in 1990), which provided housing development resources for nonprofit groups and public agencies. Both the LIHTC and HOME programs have been criticized for not being targeted at very poor households.

6. In addition, 1967 is the year of the filing of the lawsuit against the Chicago Housing Authority and the Department of Housing and Urban Development on the grounds that site selection for public housing in Chicago had been used to promote racial segregation. The ruling in favor of the plaintiffs came in 1969. See Bradford Hunt [1] for a retrospective assessment of this lawsuit.

7. An early study of public housing units in towns and cities by Aiken and Alford [9] controlled for the population of the municipality and percentage of housing that was recorded as dilapidated in 1950, and then tested several variables separately. Various measures of poverty were found to be statistically significant. This study emphasized the possible influences of politics and governmental structure on public housing. Cities that voted more heavily for the Democratic party in 1964 had more public housing, and cities with the city manager form of government had fewer public housing units. In contrast, the focus of the present study is on the basic economic factors that provided the rationale for the public housing program.

8. Other regression results not shown in the text include the following. Public housing units as of 1967 divided by the 1950 city population are a function of owner occupancy and poverty as

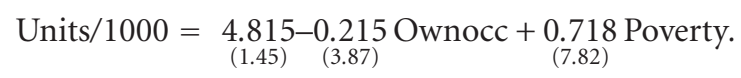

The adjusted R-squared for this estimated equation is 0.627 . None of the other variables listed in the text achieved statistical significance.

9. K. Taeuber and A. Taeuber [8] employed the "index of dissimilarity," which is the maximum distance between the two curves that describe the cumulative percentages of white and nonwhite populations. For example, suppose that the city consists of four zones with cumulative total populations and cumulative percentages as in Table 11. The index of dissimilarity is 80 because this is the maximum difference between the two cumulative percentages. Now suppose that one more zone with 50 white residents is added (listed below as Zone 3), so that the cumulative totals and percentages are as in Table 12. The index of dissimilarity has increased from 80 to 85.7 , so annexation has increased the segregation index. 
TABLe 11

White population

Zone White Pop. Cumulative White Pop. Cumulative percentage Nonwhite Pop.
Nonwhite population

Cumulative nonwhite population

$\begin{array}{cc}0 & 0 \% \\ 0 & 0 \% \\ 25 & 33 \% \\ 75 & 100 \%\end{array}$

$00 \%$
Cumulative

0

0

25

50

TABLE 12

\section{White population}

Zone White Pop. Cumulative white Pop. Cumulative percentage

Nonwhite Pop.
0
0
0
25
50

Nonwhite population

Cumulative nonwhite Cumulative percentage population nonwhite

$\begin{array}{ll}28.6 \% & 0 \\ 57.1 \% & 0 \\ 85.7 \% & 0 \\ 100 \% & 25 \\ 100 \% & 50\end{array}$

\begin{tabular}{cc}
0 & $0 \%$ \\
0 & $0 \%$ \\
0 & $0 \%$ \\
25 & $33 \%$ \\
75 & $100 \%$ \\
\hline
\end{tabular}

10. The HOPE VI program replaces demolished high-rise public housing projects with low-rise, mixed-income developments. Some public housing residents move back into the new developments, while others receive Housing Choice vouchers and move to other neighborhoods. Current research is focused on the viability of the mixed-income developments and on the outcomes for the public housing residents. See Popkin [16]. Public housing advocates argue that HOPE VI falls short of the needs.

\section{References}

[1] D. Bradford Hunt, Blueprint for Disaster: The Unraveling of Chicago Public Housing, University of Chicago Press, Chicago, Ill, USA, 2009.

[2] E. E. Wood, Recent Trends in American Housing, Macmillan, New York, NY, USA, 1931.

[3] L. Bennett, J. Smith, and P. Wright, Where Are the Poor People to Live? Transforming Public Housing Communities, ME Sharpe, Armonk, NY, USA, 2006.

[4] J. M. Quigley and S. Raphael, "Is housing unaffordable? Why isn't it more affordable?" Journal of Economic Perspectives, vol. 18, no. 1, pp. 191-214, 2004.

[5] J. McDonald, Urban America: Growth, Crisis, and Rebirth, ME Sharpe, Armonk, NY, USA, 2008.

[6] A. Hirsch, Making the Second Ghetto: Race and Housing in Chicago, 1940-1960, Cambridge University Press, New York, NY, USA, 1983.

[7] National Commission on Urban Problems, Building the American City, U. S. Government Printing Office, Washington, DC, USA, 1968.

[8] K. Taeuber and A. Taeuber, Negroes in Cities: Residential Segregation and Neighborhood Change, Aldine Publishing, Chicago, Ill, USA, 1965.

[9] M. Aiken and R. Alford, "Community structure and innovation: the case of public housing," The American Political Science
Review, vol. 64, pp. 843-864, 1970.

[10] Don Parson, Making a Better World: Public Housing, the Red Scare, and the Direction of Modern Los Angeles, University of Minnesota Press, Minneapolis, Minn, USA, 2005.

[11] T. Sugrue, The Origins of the Urban Crisis, Princeton University Press, Princeton, NJ, USA, 1996.

[12] A. I. Seligman, "What is the second ghetto?" Journal of Urban History, vol. 29, no. 3, pp. 272-280, 2003.

[13] A. Seligman, Block by Block: Neighborhoods and Public Policy on Chicago's West Side, University of Chicago Press, Chicago, Ill, USA, 2005.

[14] W. H. Carter, M. H. Schill, and S. M. Wachter, "Polarisation, public housing and racial minorities in US cities," Urban Studies, vol. 35, no. 10, pp. 1889-1911, 1998.

[15] E. E. Wood, Slums and Blighted Areas in the United States, Federal Emergency Administration of Public Works, Washington, DC, USA, 1935, (reprinted by McGrath Publishing, 1969).

[16] S. Popkin, "The HOPE VI program: what has happened to the residents?" in Where Are the Poor to Live? Transforming Public Housing Communities, L. Bennett, J. Smith, and P. Wright, Eds., pp. 68-90, ME Sharpe, Armonk, NY, USA, 2006. 


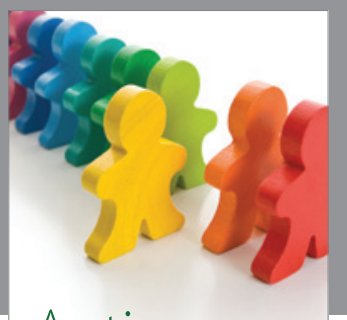

Autism

Research and Treatment
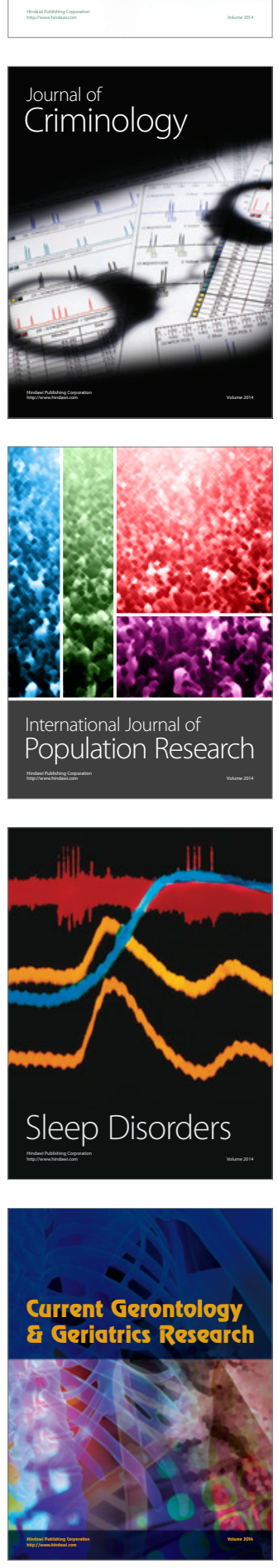
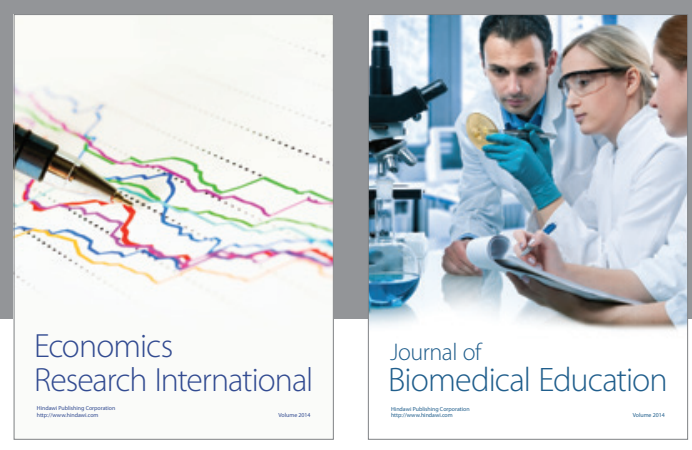

Journal of

Biomedical Education

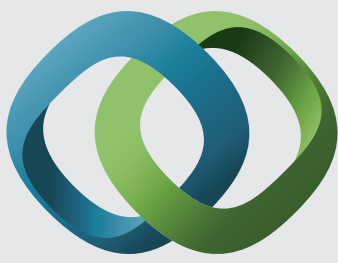

\section{Hindawi}

Submit your manuscripts at

http://www.hindawi.com
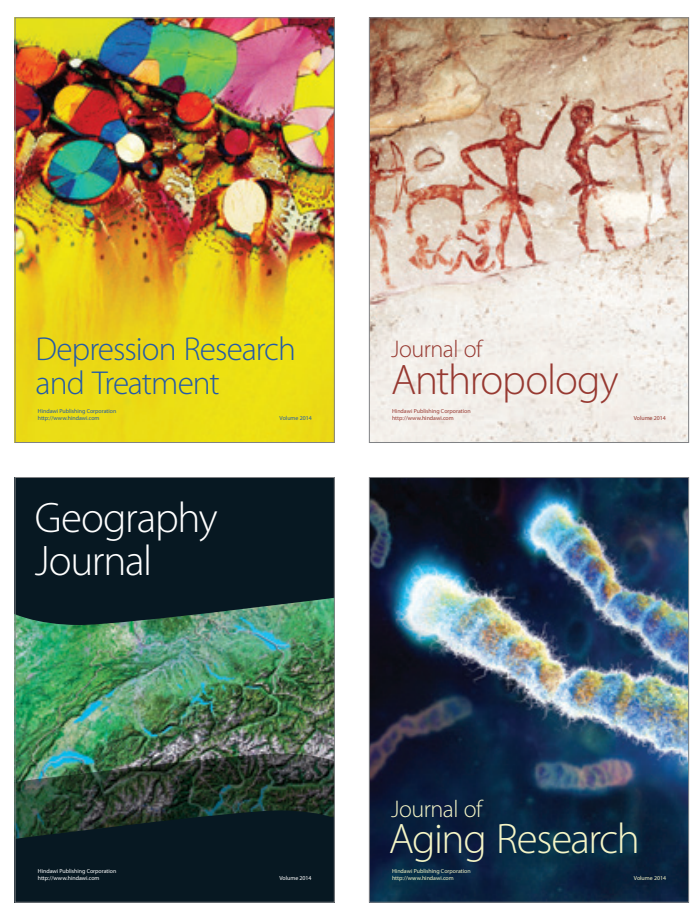

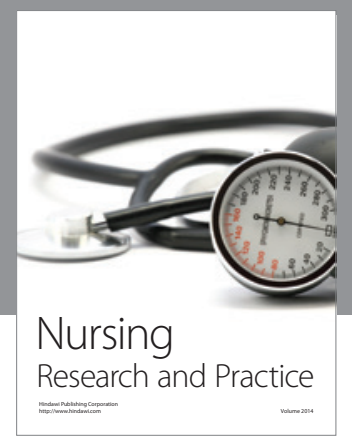

Nursing

Research and Practice

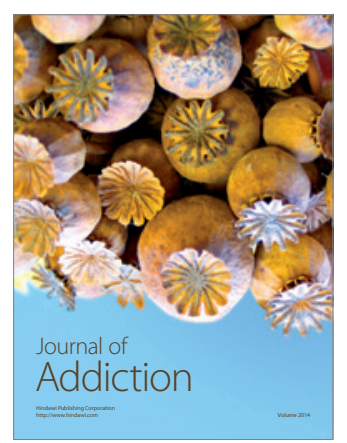

Child Development

Research

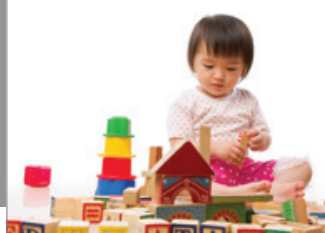

迥
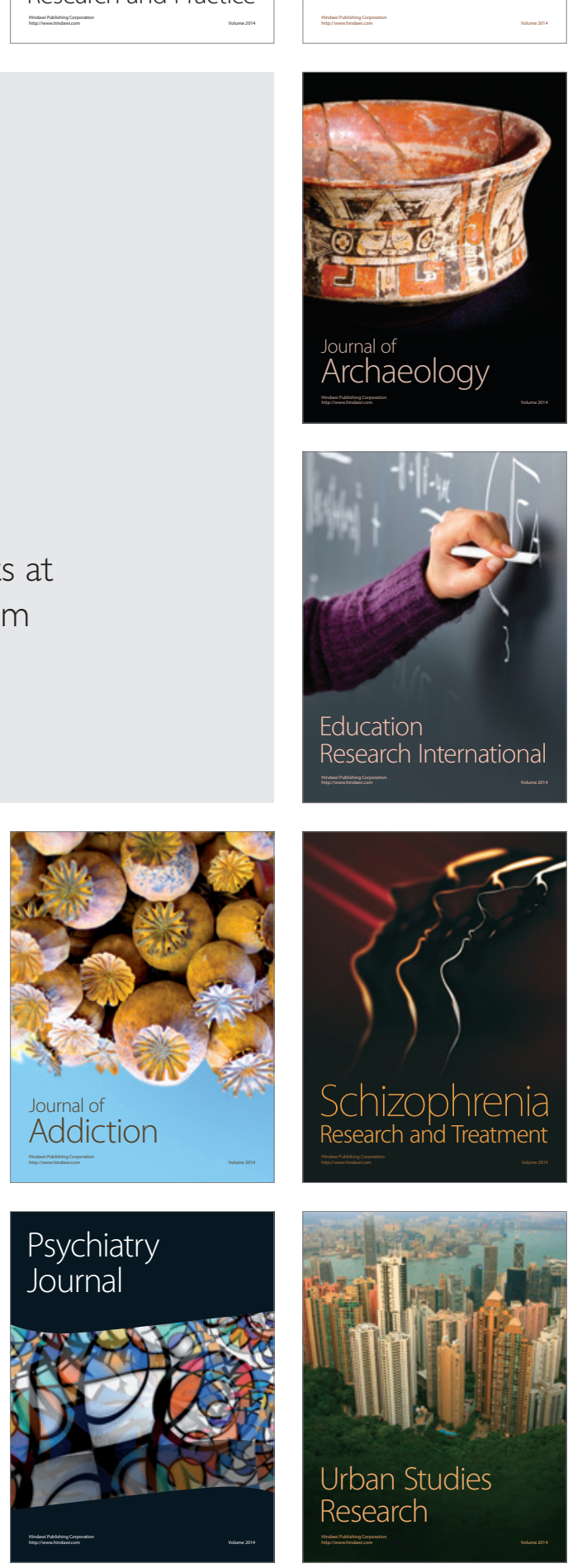